\title{
Identifying the causes of differences in ozone production from the CB05 and CBMIV chemical mechanisms
}

\author{
R. D. Saylor ${ }^{1}$ and A. F. Stein ${ }^{2, *}$ \\ ${ }^{1}$ National Oceanic and Atmospheric Administration, Air Resources Laboratory, Atmospheric Turbulence and Diffusion \\ Division, Oak Ridge, TN, USA \\ ${ }^{2}$ Earth Resources Technology, Inc., Laurel, MD, USA \\ *on assignment to: National Oceanic and Atmospheric Administration, Air Resources Laboratory, Silver Spring, MD, USA
}

Correspondence to: R. D. Saylor (rick.saylor@ noaa.gov)

Received: 30 August 2011 - Published in Geosci. Model Dev. Discuss.: 19 October 2011

Revised: 19 January 2012 - Accepted: 27 January 2012 - Published: 21 February 2012

\begin{abstract}
An investigation was conducted to identify the mechanistic differences between two versions of the carbon bond gas-phase chemical mechanism (CB05 and CBMIV) which consistently lead to larger ground-level ozone concentrations being produced in the CB05 version of the National Air Quality Forecasting Capability (NAQFC) modeling system even though the two parallel forecast systems utilize the same meteorology and base emissions and similar initial and boundary conditions. Box models of each of the mechanisms as they are implemented in the NAQFC were created and a set of 12 sensitivity simulations was designed. The sensitivity simulations independently probed the conceptual mechanistic differences between CB05 and CBMIV and were exercised over a 45 -scenario simulation suite designed to emulate the wide range of chemical regimes encountered in a continental-scale atmospheric chemistry model. Results of the sensitivity simulations indicate that two sets of reactions that were included in the CB05 mechanism, but which were absent from the CBMIV mechanism, are the primary causes of the greater ozone production in the $\mathrm{CB} 05$ version of the NAQFC. One set of reactions recycles the higher organic peroxide species of $\mathrm{CB} 05(\mathrm{ROOH})$, resulting in additional photochemically reactive products that act to produce additional ozone in some chemical regimes. The other set of reactions recycles reactive nitrogen from less reactive forms back to $\mathrm{NO}_{2}$, increasing the effective $\mathrm{NO}_{\mathrm{x}}$ concentration of the system. In particular, the organic nitrate species (NTR), which was a terminal product for reactive nitrogen in the CBMIV mechanism, acts as a reservoir species in CB05 to redistribute $\mathrm{NO}_{\mathrm{x}}$ from major source areas to potentially $\mathrm{NO}_{\mathrm{x}}-$ sensitive areas where additional ozone may be produced in areas remote from direct $\mathrm{NO}_{\mathrm{x}}$ sources.
\end{abstract}

\section{Introduction}

The NOAA National Air Quality Forecasting Capability (NAQFC) is a modeling system established in 2004 to provide ground-level ozone $\left(\mathrm{O}_{3}\right)$ forecasts for the conterminous US (CONUS) (Eder et al., 2009). The NAQFC utilizes the North American Mesoscale (NAM) meteorological model run of the Nonhydrostatic Mesoscale Model (NMM) core of the Weather Research and Forecasting (WRF) system (WRF-NMM) (Janjic, 2003) to provide meteorological fields to drive the US Environmental Protection Agency's (EPA) Community Multiscale Air Quality (CMAQ) version 4.6 modeling system (Byun and Schere, 2006) which generates 48 -h forecast fields of ground-layer $\mathrm{O}_{3}$. The CMAQ portion of the NAQFC system uses $12 \mathrm{~km}$ horizontal grid spacing and 22 vertical layers from the surface to $100 \mathrm{hPa}$. Emission inputs use the latest available EPA National Emissions Inventory with electric generating units (EGUs) updated with Continuous Emission Monitoring (CEM) data and projections to the current forecast year using data from the Department of Energy's Annual Energy Outlook. Further details of the operational NAQFC implementation and evaluations of its performance can be obtained from Eder et al. (2009), Otte et al. (2005), and Yu et al. (2010).

Since its inception, the operational version of the NAQFC has used a modified implementation of the Carbon Bond Mechanism version IV (CBMIV, Gery et al., 1989) as its gasphase chemical mechanism. An experimental version of the NAQFC has been run in parallel with the operational track to provide a testbed for planned upgrades to the operational system. Since 2008, the experimental NAQFC has employed the updated 2005 version of the Carbon Bond Mechanism (CB05, Yarwood et al., 2005) as its gas-phase mechanism. The two parallel NAQFC tracks use identical emissions base 
inventories (with volatile organic carbon compounds speciated appropriately for each mechanism), identical meteorological fields from NAM, and similar initial and boundary conditions. Figure 1 presents a comparison of domainwide daily average $\mathrm{O}_{3}$ biases for 2009 from the two parallel NAQFC systems as compared to US Environmental Protection Agency Air Quality System (AQS) measurements (http://www.epa.gov/ttn/airs/airsaqs/). Both versions of the NAQFC exhibit similar biases throughout the year, climbing from near zero in April to a peak positive bias (i.e., model - measurement) in September. The inherent, similar biases of both NAQFC versions are likely due to a variety of factors, possibly involving anthropogenic or biogenic emissions uncertainties, meteorological input biases, dry or wet deposition processes, or chemical processes common to both CB05 and CBMIV. However, the motivation of the work described here is to understand the causes of the relatively consistent difference between the operational and experimental NAQFC versions, given that the emissions and input data for both systems are identical and that they differ only in the gas-phase chemical mechanisms employed. Since the input data to both the CB05 and CBMIV versions of the NAQFC are essentially the same, it is somewhat surprising that the $\mathrm{CB} 05$ version consistently produces higher $\mathrm{O}_{3}$ surface concentrations. The purpose of the work reported here was to identify the mechanistic reasons for these differences so that future work can be undertaken to improve the forecast performance of the $\mathrm{CB} 05$ version of the NAQFC with respect to observations.

Previous investigations (Luecken et al., 1999; Sarwar et al., 2008; Luecken et al., 2008) have also observed the differences in $\mathrm{O}_{3}$ produced from CMAQ simulations for the two mechanisms. These studies have identified mechanistic differences that might have some potential impact on $\mathrm{O}_{3}$ production, but no overriding explanatory cause emerged. As noted in Luecken et al. (2008), $\mathrm{O}_{3}$ photochemistry is complex and in the framework of a three-dimensional model simulation, numerous temporally- and spatially-varying factors may contribute to the observed differences in $\mathrm{O}_{3}$ fields between the two mechanisms. Consequently, in this work we attempt to focus solely on mechanism differences without the confounding effects of additional model processes (e.g., advection, turbulent diffusion, wet and dry deposition, etc.) that may obscure the underlying mechanistic reasons for the observed differences in $\mathrm{O}_{3}$ concentrations. Using this approach, and recognizing that $\mathrm{CB} 05$ is, in some sense, a "modified" version of CBMIV, a relatively simple comparison of the mechanisms was undertaken by performing sensitivity studies with box model versions of each to identify which mechanistic differences between CB05 and CBMIV may account for the $\mathrm{O}_{3}$ differences observed in full CMAQ simulations. In subsequent sections of this paper, we describe the box model implementation of the mechanisms and the sensitivity studies that were designed to probe mechanism differences and then we present selected results from those sensitivity runs to demonstrate our findings.

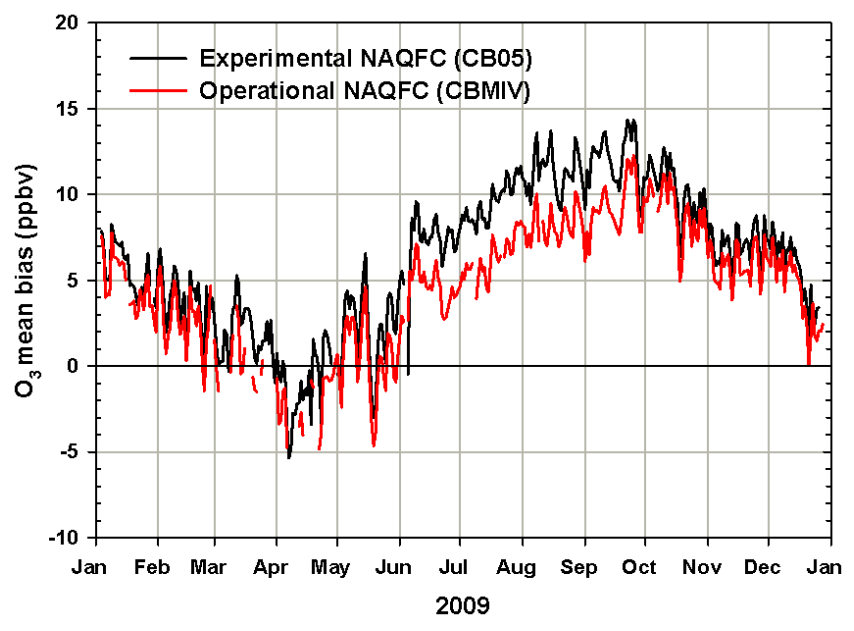

Fig. 1. Mean bias of ground-level ozone from parallel versions of the NAQFC. Ozone measurements are from the US EPA Air Quality System (AQS) measurement network. Operational NAQFC (red) and experimental NAQFC (black) mean biases (ppbv) calculated as a CONUS-wide average of (model - AQS) site biases.

\section{Methods}

\subsection{Box model description}

A box model of the convectively well-mixed boundary layer was constructed for each mechanism, CB05 and CBMIV, using a modified implementation of the Kinetic Preprocessor of Sandu and Sander (2006). It should be noted that the versions of CB05 and CBMIV that are used in the NAQFC have been altered from the mechanisms as they were originally published. In this paper, we are only concerned with and refer to CB05 and CBMIV as they have been implemented in the NAQFC system. The mechanism definition files as implemented in the NAQFC are provided as a Supplement to this paper.

After Seinfeld and Pandis (1998), but neglecting surface removal by dry deposition and mixing with background air, the concentration of a gas-phase species in a well-mixed, constant depth boundary layer is given by

$\frac{d C_{i}}{\mathrm{~d} t}=\frac{q_{i}}{H}+R_{i}$

where $C_{i}$ is the concentration of species $i$ in the boundary layer, $q_{i}$ is the emission rate of species $i$ into the boundary layer, $H$ is the boundary layer depth, and $R_{i}$ is the chemical production (or destruction) rate of species $i$. The box model for each mechanism consists of a set of equations of the form (1) for each mechanism species. In an approach fashioned after that of Zaveri and Peters (1999), a suite of 45 box model simulation scenarios was created to exercise the mechanisms across a broad range of chemical regimes, with varying $\mathrm{NO}_{\mathrm{x}}$ 
Table 1. Environmental and initial conditions for each simulation scenario.

\begin{tabular}{ll}
\hline Fixed & \\
\hline Temperature & $298 \mathrm{~K}$ \\
Pressure & $1 \mathrm{~atm}$ \\
Relative Humidity & $50 \%$ \\
$\mathrm{CO}$ & $100 \mathrm{ppbv}$ \\
$\mathrm{CH}$ & \\
\hline Initial & $1600 \mathrm{ppbv}$ \\
\hline $\mathrm{O}_{3}$ & \\
$\mathrm{NO}_{\mathrm{x}}$ & $10 \mathrm{ppbv}$ \\
$\mathrm{All} \mathrm{NMHCs}$ & 0 \\
\hline
\end{tabular}

$\left(\mathrm{NO}+\mathrm{NO}_{2}\right)$ and hydrocarbon $(\mathrm{HC})$ emission rates. Environmental conditions and initial chemical concentrations were the same for all scenarios (Table 1) so that the results from each are driven primarily by the specified emission rates (Table 2). The scenarios were designed to have emission rates and $\mathrm{HC}$ to $\mathrm{NO}_{\mathrm{x}}$ ratios that span conditions from urban to rural environments that might be encountered in a CONUS domain simulation of a three-dimensional model. For simplicity, emission rates were constrained to vary diurnally in proportion to the cosine of the zenith angle (night $=0$ and emission rate maximum, $E_{0}$, at solar noon) for a summer, mid-latitude location near ground level. Each simulation scenario was run for ten days to allow the system to obtain a quasi-stationary chemical state.

The total anthropogenic non-methane hydrocarbon emission rate of each scenario was calculated according to the NMHC: $\mathrm{NO}_{\mathrm{x}}$ ratio given in Table 2 and then apportioned among specific NMHC species in each mechanism as presented in Table 3. Care was taken to ensure that emissions rates of NMHC species were consistent for both CB05 and CBMIV versions of the box models. For species that are unchanged between the two mechanisms, the apportioning is the same in each (e.g., ETH, OLE, TOL, XYL and HCHO). In $\mathrm{CB} 05$, the two carbon ethane (ETHA) species was explicitly included, so PAR emissions in CB05 simulations were reduced equal to $2 \times$ the ETHA emissions as compared to the base CBMIV simulation. In CB05, the ALD2 species explicitly represents acetaldehyde and ALDX represents all other higher aldehydes; however, in CBMIV the ALD2 species alone represents acetaldehyde and other higher aldehydes. Consequently, the ALD2 emissions used in the base CBMIV simulations account for both the ALD2 and ALDX emissions included in $\mathrm{CB} 05$ simulations. Furthermore, emissions of the internal olefin species, IOLE, are treated as $2 \times$ ALD2 in the base CBMIV simulation (assuming 2-butene as the internal olefin). As a result, ALD2 emissions in the base CBMIV simulation are calculated as $(\mathrm{ALD} 2+\mathrm{ALDX})_{\mathrm{CB} 05}+2 \times$ (IOLE) $)_{\text {CB05. }}$.
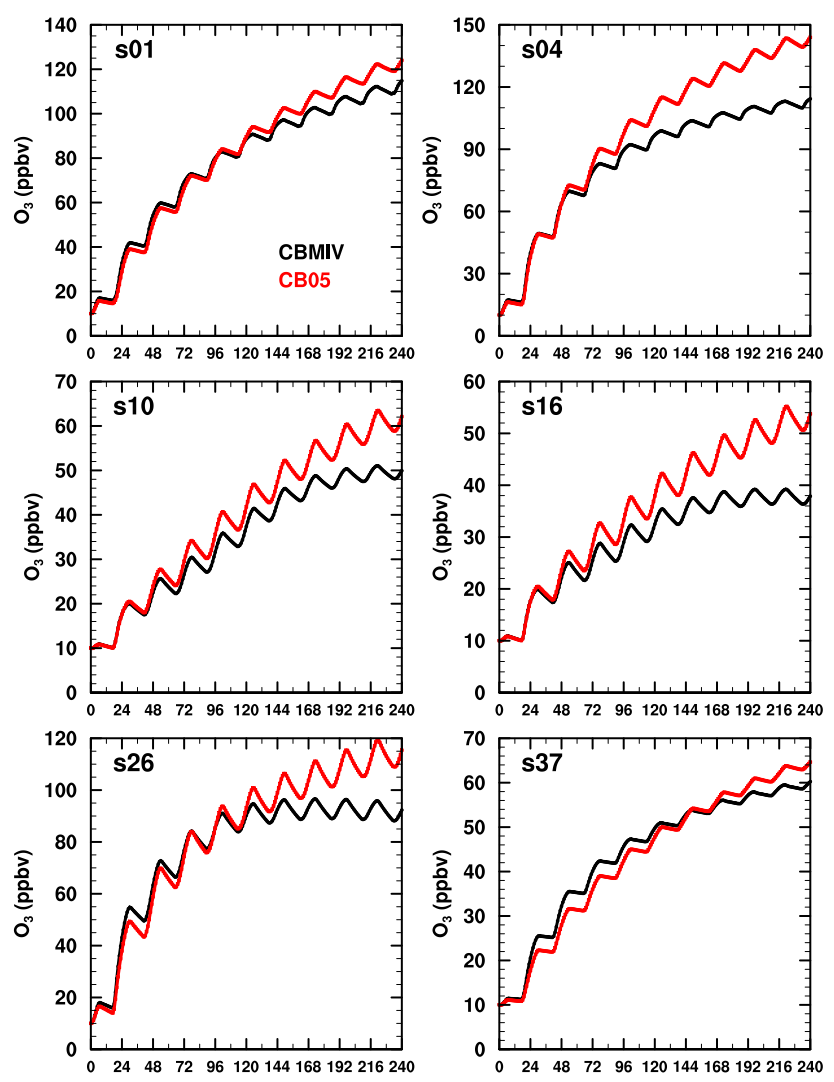

Fig. 2. Example scenario results from the simulation suite. Ozone mixing ratios (ppbv) for the base CB05 (red) and CBMIV (black) mechanisms over the $240 \mathrm{~h}$ simulation period.

Figure 2 presents results from several example scenarios from the box model simulation suite, illustrating how for a given set of emissions rates, the CB05 mechanism almost invariably produces higher $\mathrm{O}_{3}$ values by the end of the 10day simulation period. The behavior illustrated here from the box model versions of CBMIV and CB05 is consistent with the behavior observed from the parallel versions of the NAQFC system.

\subsection{Sensitivity tests}

Beyond routine updates of reaction rate coefficients, the mechanistic differences between CB05 and CBMIV are extensive but can be summarized briefly into 11 conceptual groups: (1) addition of molecular hydrogen reactions to improve odd-hydrogen chemistry in the upper troposphere; (2) addition of reactions involving odd-oxygen and oddhydrogen to provide a more complete description of hydroxyl radical $(\mathrm{OH})$ chemistry; (3) addition of nitrate radical $\left(\mathrm{NO}_{3}\right)$ reactions to improve the representation of nocturnal chemistry in the boundary layer; (4) addition of inorganic $\mathrm{NO}_{\mathrm{x}}$ recycling reactions that slowly recycle $\mathrm{HNO}_{3}$, $\mathrm{HO}_{2} \mathrm{NO}_{2}$, and $\mathrm{N}_{2} \mathrm{O}_{5}$ back into $\mathrm{NO}_{2} ;(5)$ addition of reactions 
Table 2. Scenario Maximum Emission Rates $\left(E_{0}\right)$ for the Box Model Simulation Suite (hourly emission rate $=E_{0} \times \cos \left(\theta_{z}\right) ; \theta_{z}=$ zenith angle).

\begin{tabular}{|c|c|c|c|c|}
\hline Scenario & $\begin{array}{r}\mathrm{NO}_{\mathrm{x}} \\
\left(\mu \mathrm{mol} \mathrm{m}{ }^{-2} \mathrm{~h}^{-1}\right)\end{array}$ & $\begin{array}{r}R_{\mathrm{NMHC}} \\
\left(\mathrm{mol} \mathrm{NMHC} / \mathrm{mol} \mathrm{NO}_{\mathrm{x}}\right)\end{array}$ & $\begin{array}{r}\text { ISOP } \\
\left(\mu \mathrm{mol} \mathrm{m}{ }^{-2} \mathrm{~h}^{-1}\right)\end{array}$ & $\begin{array}{r}\text { TERP } \\
\left(\mu \mathrm{mol} \mathrm{m}{ }^{-2} \mathrm{~h}^{-1}\right)\end{array}$ \\
\hline s01 & 5 & 1 & 0 & 0 \\
\hline $\mathrm{s} 02$ & 20 & 1 & 0 & 0 \\
\hline $\mathrm{s} 03$ & 40 & 1 & 0 & 0 \\
\hline s04 & 5 & 10 & 0 & 0 \\
\hline s05 & 20 & 10 & 0 & 0 \\
\hline s06 & 40 & 10 & 0 & 0 \\
\hline s07 & 5 & 100 & 0 & 0 \\
\hline s08 & 20 & 100 & 0 & 0 \\
\hline s09 & 40 & 100 & 0 & 0 \\
\hline s10 & 1 & 0.1 & 50 & 0 \\
\hline s11 & 5 & 0.1 & 50 & 0 \\
\hline $\mathrm{s} 12$ & 10 & 0.1 & 50 & 0 \\
\hline s13 & 1 & 1 & 50 & 0 \\
\hline s14 & 5 & 1 & 50 & 0 \\
\hline s15 & 10 & 1 & 50 & 0 \\
\hline s16 & 1 & 10 & 50 & 0 \\
\hline s17 & 5 & 10 & 50 & 0 \\
\hline s18 & 10 & 10 & 50 & 0 \\
\hline s19 & 1 & 0.1 & 50 & 10 \\
\hline $\mathrm{s} 20$ & 5 & 0.1 & 50 & 10 \\
\hline s21 & 10 & 0.1 & 50 & 10 \\
\hline s22 & 1 & 1 & 50 & 10 \\
\hline $\mathrm{s} 23$ & 5 & 1 & 50 & 10 \\
\hline s24 & 10 & 1 & 50 & 10 \\
\hline $\mathrm{s} 25$ & 1 & 10 & 50 & 10 \\
\hline s26 & 5 & 10 & 50 & 10 \\
\hline s27 & 10 & 10 & 50 & 10 \\
\hline s 28 & 5 & 1 & 0 & 1 \\
\hline s29 & 20 & 1 & 0 & 1 \\
\hline s30 & 40 & 1 & 0 & 1 \\
\hline s31 & 5 & 10 & 0 & 1 \\
\hline s32 & 20 & 10 & 0 & 1 \\
\hline s33 & 40 & 10 & 0 & 1 \\
\hline s34 & 5 & 100 & 0 & 1 \\
\hline s35 & 20 & 100 & 0 & 1 \\
\hline s36 & 40 & 100 & 0 & 1 \\
\hline s37 & 1 & 0.1 & 0 & 1 \\
\hline s38 & 5 & 0.1 & 0 & 1 \\
\hline s39 & 10 & 0.1 & 0 & 1 \\
\hline $\mathrm{s} 40$ & 1 & 1 & 0 & 1 \\
\hline s41 & 5 & 1 & 0 & 1 \\
\hline $\mathrm{s} 42$ & 10 & 1 & 0 & 1 \\
\hline $\mathrm{s} 43$ & 1 & 10 & 0 & 1 \\
\hline s44 & 5 & 10 & 0 & 1 \\
\hline s45 & 10 & 10 & 0 & 1 \\
\hline
\end{tabular}

that recycle the lumped organic nitrate species (NTR) back to $\mathrm{HNO}_{3}$ and $\mathrm{NO}_{2}$; (6) substitution of explicit chemistry for methane $\left(\mathrm{CH}_{4}\right)$ oxidation and the introduction of the methylperoxy radical $\left(\mathrm{CH}_{3} \mathrm{O}_{2}\right)$ instead of the highly parameterized representation in CBMIV; (7) addition of a reaction for OH oxidation of ethane (ETHA) rather than lumping with the PAR species; (8) introduction of a new higher aldehyde species that separates the lumped CBMIV aldehyde species into acetaldehyde (ALD2) and the higher aldehyde (ALDX) and introduces related species such as peroxyacyl radicals 
Table 3. Nonmethane Hydrocarbon (NMHC) species apportionment.

\begin{tabular}{lrrlr}
\hline CBMIV & $\begin{array}{r}\mathrm{mol} \mathrm{mol}^{-1} \\
\text { NMHC }\end{array}$ & & CB05 & $\begin{array}{r}\mathrm{mol} \mathrm{mol}^{-1} \\
\text { NMHC }\end{array}$ \\
\cline { 1 - 2 } \cline { 5 - 5 } PAR & 0.860 & & PAR & 0.845 \\
& & & ETHA & 0.0075 \\
ETH & 0.050 & & ETH & 0.050 \\
OLE & 0.005 & & OLE & 0.005 \\
& & & IOLE & 0.005 \\
TOL & 0.030 & & TOL & 0.030 \\
XYL & 0.020 & & XYL & 0.020 \\
HCHO & 0.010 & & HCHO & 0.010 \\
ALD2 & 0.030 & & ALD2 & 0.015 \\
& & & ALDX & 0.005 \\
\hline
\end{tabular}

(CXO3), peroxynitrates (PANX), carboxylic acids (AACD) and peroxycarboxylic acids (PACD); (9) separation of the CBMIV alkene species into a lumped internal olefin (IOLE) and other olefins (OLE); (10) addition of higher organic peroxides $(\mathrm{ROOH})$ were added to improve the overall representation of peroxide species which are important in aqueous sulfate production; and (11) addition of a new species (TERP) to represent terpene chemistry more explicitly.

The full CB05 mechanism represents the combined impact of these 11 mechanistic updates. Based upon these groups, 12 sensitivity simulations, described in the following sections, were designed to probe the impact of individual differences on overall $\mathrm{O}_{3}$ production between the $\mathrm{CB} 05$ and CBMIV mechanisms. Each sensitivity test was designed to probe how (or if) each particular mechanistic update of CBMIV impacted $\mathrm{O}_{3}$ concentrations over the wide range of chemical regimes typically encountered in a regional-tocontinental scale simulation. As described below, each sensitivity test attempts to return one of the mechanistic updates to its previous representation in CBMIV. By then comparing $\mathrm{O}_{3}$ concentrations from the base $\mathrm{CB} 05$, the base CBMIV, and the sensitivity test (i.e., the CB05 mechanism with one particular update rolled back to its CBMIV representation) for each scenario in the simulation suite, we obtain an indication of which particular mechanism change or changes may account for the observed larger $\mathrm{O}_{3}$ produced by $\mathrm{CB} 05$.

\subsection{1 $\mathrm{xH2}$}

Two reactions were added to the CB05 mechanism that do not appear in CBMIV to account for molecular hydrogen reactions (all reaction numbers refer to the mechanisms as implemented in the NAQFC as provided in the Supplement)

$$
\begin{array}{ll}
\mathrm{O}\left({ }^{1} \mathrm{D}\right)+\mathrm{H}_{2}\left(+\mathrm{O}_{2}\right) & \rightarrow \mathrm{OH}+\mathrm{HO}_{2} \\
\mathrm{OH}+\mathrm{H}_{2} & \rightarrow \mathrm{HO}_{2}
\end{array}
$$

For sensitivity test $\mathrm{xH} 2$, these reactions were removed from CB05, leaving all other reactions as in the base CB05 mechanism. No emissions changes were made in the scenario suite.

\subsection{2 xoddH\&O}

Six reactions were included in the CB05 mechanism which do not appear in CBMIV in order to better represent oddoxygen and odd-hydrogen chemistry

$$
\begin{aligned}
& \mathrm{OH}+\mathrm{O} \rightarrow \mathrm{HO}_{2} \\
& \mathrm{OH}+\mathrm{OH} \rightarrow \mathrm{O}+\mathrm{H}_{2} \mathrm{O} \\
& \mathrm{OH}+\mathrm{OH} \rightarrow \mathrm{H}_{2} \mathrm{O}_{2} \\
& \mathrm{OH}+\mathrm{HO}_{2} \rightarrow \mathrm{H}_{2} \mathrm{O}+\mathrm{O}_{2} \\
& \mathrm{HO}_{2}+\mathrm{O} \rightarrow \mathrm{OH}+\mathrm{O}_{2} \\
& \mathrm{H}_{2} \mathrm{O}_{2}+\mathrm{O} \rightarrow \mathrm{OH}+\mathrm{HO}_{2}
\end{aligned}
$$

For sensitivity test xoddH\&O, these reactions were removed from CB05, leaving all other reactions as in the base CB05 mechanism. No emissions changes were made to the scenario suite.

\subsection{3 xNO3night}

Six reactions were introduced into the $\mathrm{CB} 05$ mechanism that are not included in CBMIV in order to better represent $\mathrm{NO}_{3}$ radical chemistry in the nocturnal boundary layer

$$
\begin{aligned}
& \mathrm{NO}_{3}+\mathrm{O} \rightarrow \mathrm{NO}_{2}+\mathrm{O}_{2} \\
& \mathrm{NO}_{3}+\mathrm{OH} \rightarrow \mathrm{NO}_{2}+\mathrm{HO}_{2} \\
& \mathrm{NO}_{3}+\mathrm{HO}_{2} \rightarrow \mathrm{HNO}_{3} \\
& \mathrm{NO}_{3}+\mathrm{O}_{3} \rightarrow \mathrm{NO}_{2}+2 \mathrm{O}_{2} \\
& \mathrm{NO}_{3}+\mathrm{NO}_{3} \rightarrow 2 \mathrm{NO}_{2} \\
& \mathrm{NO}_{3}+\mathrm{ETH} \rightarrow \mathrm{NO}_{2}+\mathrm{XO} 2+2 \mathrm{HCHO}
\end{aligned}
$$

For sensitivity test xNO3night, these reactions were removed from CB05, leaving all other reactions as in the base CB05 mechanism. No emissions changes were made to the scenario suite.

\subsubsection{XETHA}

A reaction was introduced in $\mathrm{CB} 05$ to account for the explicit reaction of ethane (ETHA) with $\mathrm{OH}$

$$
\begin{array}{r}
\mathrm{ETHA}+\mathrm{OH} \rightarrow \begin{array}{r}
0.991 \mathrm{ALD} 2+0.991 \mathrm{XO} 2 \\
+0.009 \mathrm{XO} 2 \mathrm{~N}+\mathrm{HO}_{2}
\end{array}
\end{array}
$$

In sensitivity test XETHA, this reaction was removed and all ETHA emissions in the scenario suite were converted to the equivalent PAR emissions as in CBMIV.

\subsection{5 xALDX}

In CBMIV, the ALD2 species represents acetaldehyde $\left(\mathrm{CH}_{3} \mathrm{CHO}\right)$ and all $\mathrm{C}_{3}$ and higher aldehydes. However, in CB05, ALD2 explicitly represents only acetaldehyde while a 
new species, ALDX, is included to represent $\mathrm{C}_{3}$ and higher aldehydes. In CB05, ALDX produces $\mathrm{C}_{3}$ and higher acylperoxy radicals, $\mathrm{CXO} 3$, in reactions which are analogous to the explicit production of acetylperoxy, $\mathrm{C} 2 \mathrm{O} 3$.

$$
\begin{aligned}
& \mathrm{ALD} 2+\mathrm{NO} \rightarrow \mathrm{C} 2 \mathrm{O} 3+\mathrm{OH} \\
& \mathrm{ALD} 2+\mathrm{OH} \rightarrow \mathrm{C} 2 \mathrm{O} 3 \\
& \mathrm{ALD} 2+\mathrm{NO}_{3} \rightarrow \mathrm{C} 2 \mathrm{O} 3+\mathrm{HNO}_{3} \\
& \mathrm{ALD} 2+h v \rightarrow \mathrm{MEO} 2+\mathrm{CO}+\mathrm{HO}_{2} \\
& \mathrm{ALDX}+\mathrm{NO} \rightarrow \mathrm{CXO} 3+\mathrm{OH} \\
& \mathrm{ALDX}+\mathrm{OH} \rightarrow \mathrm{CXO} 3 \\
& \mathrm{ALDX}+\mathrm{NO}_{3} \rightarrow \mathrm{CXO} 3+\mathrm{HNO}_{3} \\
& \mathrm{ALDX}+h v \rightarrow \mathrm{MEO} 2+\mathrm{CO}+\mathrm{HO}_{2}
\end{aligned}
$$

The acylperoxy radicals may then proceed to react with $\mathrm{NO}_{2}$ to produce a $\mathrm{C}_{3}$ and higher peroxyacyl nitrate species, PANX, again in a manner analogous to the explicit acetylperoxy radical, allowing PAN to explicitly represent only peroxyacetyl nitrate.

$\mathrm{C} 2 \mathrm{O} 3+\mathrm{NO} \rightarrow \mathrm{MEO} 2+\mathrm{NO}_{2}$

$\mathrm{C} 2 \mathrm{O} 3+\mathrm{NO}_{2} \rightarrow$ PAN

$\mathrm{CXO} 3+\mathrm{NO} \rightarrow \mathrm{ALD} 2+\mathrm{NO}_{2}+\mathrm{HO}_{2}+\mathrm{XO} 2$

$\mathrm{CXO} 3+\mathrm{NO}_{2} \rightarrow$ PANX

In CB05, both PAN and PANX may decompose back to the peroxy radical and $\mathrm{NO}_{2}$ via thermal or photolytic processes.

$$
\begin{array}{ll}
\mathrm{PAN} & \rightarrow \mathrm{C} 2 \mathrm{O} 3+\mathrm{NO}_{2} \\
\mathrm{PAN}+h v & \rightarrow \mathrm{C} 2 \mathrm{O} 3+\mathrm{NO}_{2} \\
\mathrm{PANX} & \rightarrow \mathrm{CXO} 3+\mathrm{NO}_{2} \\
\mathrm{PANX}+h v & \rightarrow \mathrm{CXO} 3+\mathrm{NO}_{2}
\end{array}
$$

Additionally, PANX may react with $\mathrm{OH}$ radical to recycle nitrogen back to $\mathrm{NO}_{2}$.

$\mathrm{PANX}+\mathrm{OH} \rightarrow \mathrm{ALD} 2+\mathrm{NO}_{2}$

For sensitivity test XALDX, the higher aldehyde chemistry of CB05 is converted back to the CBMIV representation, thus requiring that ALD2 represent both acetaldehyde and the $\mathrm{C}_{3}$ and higher aldehydes. This was accomplished in CB05 by the following four steps:

1. in reactions where ALDX is a product (R61, R62, R63, R64, R112, R113, R116, R117, R118, R119, R121, R124, R125, R126, R127, R137, R143, R144, R145, R147, R149, R150, R151, R152, R154, and R156), ALDX is replaced by ALD2, ensuring the total stoichiometric production of higher aldehydes is conserved;

2. reactions where ALDX is a reactant are removed (R98, R99, R100, and R101);
3. PAN chemistry is converted to the CBMIV representation by removing reactions where PANX or CXO3 (C3 and higher acylperoxy radicals) are reactants (R102, R103, R104, R105, R106, R107, R108, R109, R110, and R111) and all CXO3 products are replaced by the CBMIV representation of higher acylperoxy radicals, C2O3 (R141, R143, R145, R147, and R151); and,

4. all ALDX emissions are replaced by ALD2 emissions.

\subsection{6 $\quad \mathrm{xexCH4}$}

In CB05, the explicit chemistry of the methylperoxy radical (MEO2) was introduced

$$
\begin{array}{lll}
\mathrm{CH}_{4}+\mathrm{OH} & \mathrm{MEO} 2 \\
\mathrm{MEO} 2+\mathrm{NO} \rightarrow & \mathrm{HCHO}+\mathrm{HO}_{2}+\mathrm{NO}_{2} \\
\mathrm{MEO} 2+\mathrm{HO}_{2} \rightarrow & \mathrm{MEPX} \\
\mathrm{MEO} 2+\mathrm{MEO} 2 \rightarrow & 1.37 \mathrm{HCHO}+0.74 \mathrm{HO}_{2} \\
& +0.63 \mathrm{MEOH} \\
\mathrm{MEPX}+\mathrm{OH} \rightarrow & 0.7 \mathrm{MEO}+0.3 \mathrm{XO} 2+ \\
\mathrm{MEPX}+h v+ & 0.3 \mathrm{HO}_{2} \\
\mathrm{MEOH}+\mathrm{OH} \rightarrow & \mathrm{HCHO}+\mathrm{HO}_{2}+\mathrm{OH} \\
\mathrm{C} 2 \mathrm{O} 3+\mathrm{MEO} 2 \rightarrow & 0.9 \mathrm{MEO} 2+0.9 \\
& \mathrm{HO}_{2}+\mathrm{HCHO}+0.1 \mathrm{AACD} \\
& \\
\mathrm{CXO} 3+\mathrm{MEO} 2 \rightarrow & 0.9 \mathrm{ALD} 2+0.9 \times 2+\mathrm{HO}_{2} \\
& +0.1 \mathrm{AACD}+0.1 \mathrm{HCHO}
\end{array}
$$

to better represent remote tropospheric chemistry. In sensitivity test xexCH4, the products of the $\mathrm{CH}_{4}+\mathrm{OH}$ Reaction (R66) are returned to the CMBIV representation, where $\mathrm{MEO} 2$ is replaced by $\mathrm{HCHO}+\mathrm{XO} 2+\mathrm{HO}_{2}$,

$\mathrm{CH}_{4}+\mathrm{OH} \rightarrow \mathrm{HCHO}+\mathrm{XO} 2+\mathrm{HO}_{2}$.

and Reactions (R66), (R67), (R68), (R69), (R70), (R71), (R72), (R92) and (R108) are removed. In additional reactions where MEO2 is a product (Reactions R86, R87, R92, $\mathrm{R} 96, \mathrm{R} 97, \mathrm{R} 101$, and R111), MEO2 is also replaced with $\mathrm{HCHO}+\mathrm{XO} 2+\mathrm{HO}_{2}$ (i.e., these reactions are returned to their CBMIV representation).

\subsection{7 $\mathrm{xROOH}$}

In $\mathrm{CB} 05$, a lumped organic peroxide species ( $\mathrm{ROOH})$ was introduced. It is formed as a product of each of the peroxy operator species, $\mathrm{XO} 2$ and $\mathrm{XO} 2 \mathrm{~N}$, reacting with hydroperoxyl radical $\left(\mathrm{HO}_{2}\right)$

$\mathrm{XO} 2+\mathrm{HO}_{2} \rightarrow \mathrm{ROOH}$

$\mathrm{XO} 2 \mathrm{~N}+\mathrm{HO}_{2} \rightarrow \mathrm{ROOH}$ 
In CBMIV, these two reactions produced only an inert product; however, in $\mathrm{CB} 05$ the $\mathrm{ROOH}$ species can react via

$$
\begin{aligned}
\mathrm{ROOH}+\mathrm{OH} \rightarrow & \mathrm{XO} 2+0.5 \mathrm{ALD} 2+0.5 \mathrm{ALDX} \\
\mathrm{ROOH}+h v \rightarrow & \mathrm{OH}+\mathrm{HO}_{2}+0.5 \mathrm{ALD} 2 \\
& +0.5 \mathrm{ALDX}
\end{aligned}
$$

to produce photochemically active products. In sensitivity test $\mathrm{xROOH}$, the Reactions (R63) and (R64) were removed from $\mathrm{CB} 05$, leaving all other reactions as in the base CB05 mechanism. By removing these two reactions from the mechanism, Reactions (R56) and (R57) produce an inert product as in CBMIV. No emissions changes were made to the scenario suite.

\subsection{8 xIOLE}

In CB05, an internal alkene species (IOLE) was introduced to better represent the chemistry of these species.

$$
\begin{array}{rlrr}
\mathrm{IOLE}+\mathrm{O} \rightarrow & 1.24 \mathrm{ALD} 2+0.66 \mathrm{ALDX} & (\mathrm{R} 124) \\
& +0.1 \mathrm{HO}_{2}+0.1 \mathrm{XO} 2+0.1 \mathrm{CO}+0.1 \mathrm{PAR} \\
\mathrm{IOLE}+\mathrm{OH} \rightarrow & 1.3 \mathrm{ALD} 2+0.7 \mathrm{ALDX}+\mathrm{HO}_{2} & \\
& +\mathrm{XO} 2 & (\mathrm{R} 125) \\
\mathrm{IOLE}+\mathrm{O}_{3} \rightarrow & 0.65 \mathrm{ALD} 2+0.35 \mathrm{ALDX} & (\mathrm{R} 126) \\
& +0.25 \mathrm{HCHO}+0.25 \mathrm{CO}+0.5 \mathrm{O}+0.5 \mathrm{OH} \\
& +0.5 \mathrm{HO}_{2} \\
\mathrm{IOLE}+\mathrm{NO}_{3} \rightarrow & 1.18 \mathrm{ALD}_{2}+0.64 \mathrm{ALDX}+\mathrm{HO}_{2} & \\
& & +\mathrm{NO}_{2} & (\mathrm{R} 127)
\end{array}
$$

In CBMIV, the chemistry of internal alkenes is approximated by the direct emission of the aldehyde products (as ALD2) that are formed in their oxidation reactions. In sensitivity test xIOLE, the IOLE Reactions (R124), (R125), (R126) and (R127) are removed and the oxidation reactions

\begin{tabular}{|c|c|}
\hline Name & Brief Description \\
\hline $\mathrm{xH} 2$ & $\begin{array}{l}\text { Reactions involving molecular } \\
\text { hydrogen removed }\end{array}$ \\
\hline xoddH\&O & $\begin{array}{l}\text { Additional odd } \mathrm{H} \text { and odd } \mathrm{O} \text { reactions } \\
\text { removed }\end{array}$ \\
\hline xNO3night & $\begin{array}{l}\text { Additional } \mathrm{NO}_{3} \text { radical reactions } \\
\text { removed }\end{array}$ \\
\hline xETHA & $\begin{array}{l}\text { Explicit ethane chemistry removed; } \\
\text { ETHA emissions as PAR }\end{array}$ \\
\hline xALDX & $\begin{array}{l}\text { Higher aldehyde chemistry converted } \\
\text { back to CBMIV representation; all } \\
\text { ALDX emissions converted to ALD2 }\end{array}$ \\
\hline $\mathrm{xexCH} 4$ & $\begin{array}{l}\text { Explicit methane chemistry removed } \\
\text { and replaced with CBMIV } \\
\text { representation }\end{array}$ \\
\hline $\mathrm{xROOH}$ & $\begin{array}{l}\text { Organic peroxide destruction reactions } \\
\text { removed }\end{array}$ \\
\hline xIOLE & $\begin{array}{l}\text { Internal olefin chemistry removed; all } \\
\text { olefin emissions as OLE }\end{array}$ \\
\hline XTERP & $\begin{array}{l}\text { Explicit TERP chemistry removed; } \\
\text { terpene emissions apportioned as PAR, } \\
\text { OLE and ALD2 }\end{array}$ \\
\hline xiNOxrecycle & $\begin{array}{l}\text { New inorganic } \mathrm{NO}_{\mathrm{x}} \text { recycling reactions } \\
\text { removed }\end{array}$ \\
\hline xNTRrecycle & NTR recycling reactions removed \\
\hline xallNOxrecycle & $\begin{array}{l}\text { Both NTR and inorganic } \mathrm{NO}_{\mathrm{X}} \text { recycling } \\
\text { reactions removed }\end{array}$ \\
\hline
\end{tabular}
of the original alkene species (OLE) (Reactions R116, R117, $\mathrm{R} 118$, and R119) are replaced by their CBMIV versions

$$
\begin{aligned}
\mathrm{OLE}+\mathrm{O} \rightarrow & 0.63 \mathrm{ALD} 2+0.38 \mathrm{HO}_{2} \quad(\mathrm{R} 1 \\
& +0.28 \mathrm{XO} 2+0.3 \mathrm{CO}+0.2 \mathrm{HCHO} \\
+ & 0.02 \mathrm{XO} 2 \mathrm{~N}+0.22 \mathrm{PAR}+0.2 \mathrm{OH} \\
\mathrm{OLE}+\mathrm{OH} \rightarrow & \mathrm{HCHO}+\mathrm{ALD} 2+\mathrm{HO}_{2} \\
& +\mathrm{XO} 2-\mathrm{PAR} \\
\mathrm{OLE}+\mathrm{O}_{3} \rightarrow & 0.5 \mathrm{ALD} 2+0.74 \mathrm{HCHO} \quad(\mathrm{R} 11 \\
& +0.33 \mathrm{CO}+0.1 \mathrm{OH}+0.44 \mathrm{HO}_{2} \\
+ & 0.22 \mathrm{XO} 2+0.2 \mathrm{FACD}+0.2 \mathrm{AACD} \\
& -\mathrm{PAR} \\
\mathrm{OLE}+\mathrm{NO}_{3} \rightarrow & 0.91 \mathrm{XO} 2+\mathrm{ALD} 2+\mathrm{HCHO} \\
+ & 0.09 \mathrm{XO} 2 \mathrm{~N}+\mathrm{NO}_{2}-\mathrm{PAR} \quad(\mathrm{R} 1
\end{aligned}
$$

and the emissions of IOLE are replaced by emissions of $2 x$ ALD2 (assuming that all of the IOLE represented 2-butene).
Table 4. Description of box model sensitivity tests.

\subsubsection{XTERP}

In CB05, the TERP species was introduced to represent terpene chemistry more explicitly. Four reactions of TERP were included

$$
\begin{array}{rlll}
\mathrm{TERP}+\mathrm{O} \rightarrow & 0.15 \mathrm{ALDX}+5.12 \mathrm{PAR} & (\mathrm{R} 149) \\
\mathrm{TERP}+\mathrm{OH} \rightarrow & 0.75 \mathrm{HO}_{2}+1.25 \mathrm{XO} 2 & (\mathrm{R} 150) \\
& +0.25 \mathrm{XO} 2 \mathrm{~N}+0.28 \mathrm{HCHO} & \\
& +1.66 \mathrm{PAR}+0.47 \mathrm{ALDX} \\
\mathrm{TERP}+\mathrm{O}_{3} \rightarrow & 0.57 \mathrm{OH}+0.07 \mathrm{HO}_{2}+0.76 \mathrm{XO} 2(\mathrm{R} 151) \\
& +0.18 \mathrm{XO} 2 \mathrm{~N}+0.24 \mathrm{HCHO}+0.001 \mathrm{CO} \\
\mathrm{TERP}+\mathrm{NO}_{3} \rightarrow & +7.0 \mathrm{PAR}+0.21 \mathrm{ALDX}+0.39 \mathrm{CXO} 3 \\
& +0.25 \mathrm{XO} 2 \mathrm{~N}+0.47 \mathrm{ALDX}+0.53 \mathrm{NTR}
\end{array}
$$

In the sensitivity test XTERP, these reactions were removed from CB05, leaving all other reactions as in the base CB05. TERP emissions of the scenario suite were converted 

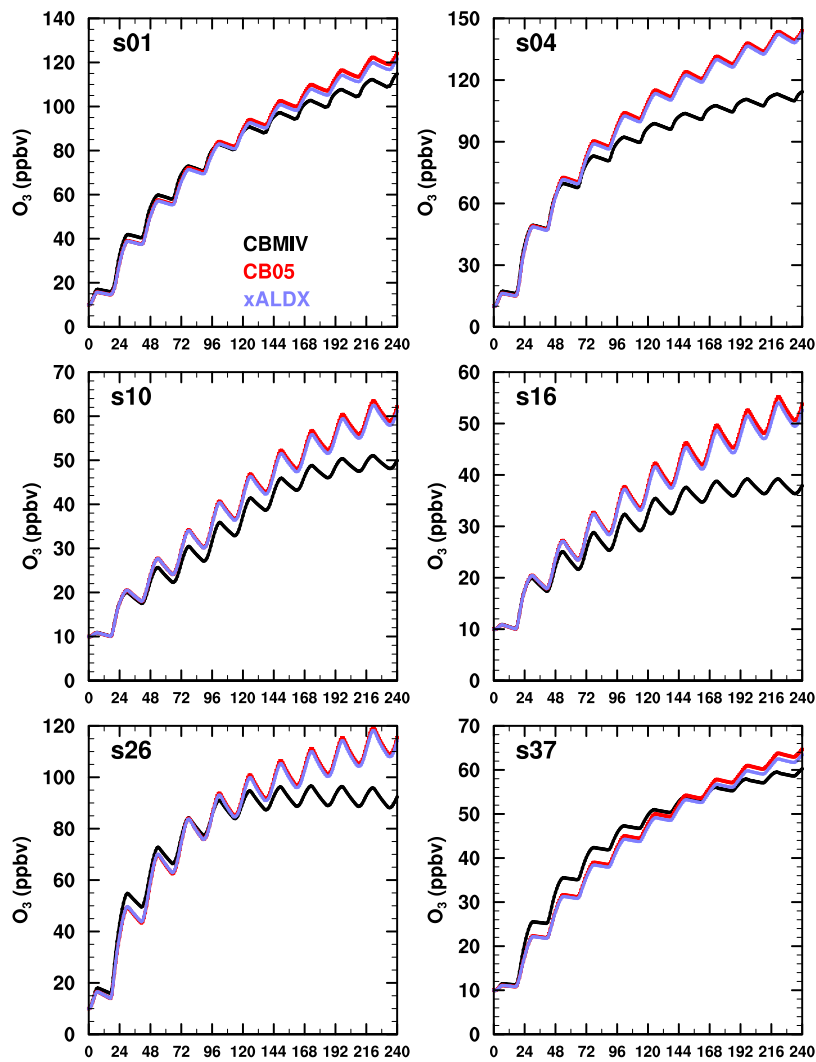

Fig. 3. Example scenario results for sensitivity test XALDX. Ozone mixing ratios (ppbv) for the base CB05 (red), base CBMIV (black) and sensitivity test XALDX (violet) over the $240 \mathrm{hr}$ simulation period.

to the equivalent CBMIV representation as 1 TERP $=1.5$ $\mathrm{ALD} 2+0.5 \mathrm{OLE}+6.0 \mathrm{PAR}$.

\subsubsection{0 xiNOxrecycle}

Three reactions were introduced into the CB05 mechanism that are not included in CBMIV which provide a pathway for recycling of reactive nitrogen species

$$
\begin{aligned}
\mathrm{HO}_{2} \mathrm{NO}_{2}+h v \rightarrow & 0.61 \mathrm{HO}_{2}+0.61 \mathrm{NO}_{2} \\
& +0.39 \mathrm{OH}+0.39 \mathrm{NO}_{3} \\
\mathrm{HNO}_{3}+h v \rightarrow & \mathrm{OH}+\mathrm{NO}_{2} \\
\mathrm{~N}_{2} \mathrm{O}_{5}+h v \rightarrow & \mathrm{NO}_{2}+\mathrm{NO}_{3}
\end{aligned}
$$

For sensitivity test xiNOxrecycle, these reactions were removed from $\mathrm{CB} 05$, leaving all other reactions as in the base CB05 mechanism. No emissions changes were made to the scenario suite.

\subsubsection{1 xNTRrecycle}

The chemistry of lumped organic nitrate (NTR) was altered substantially in CB05. The yield of NTR production from
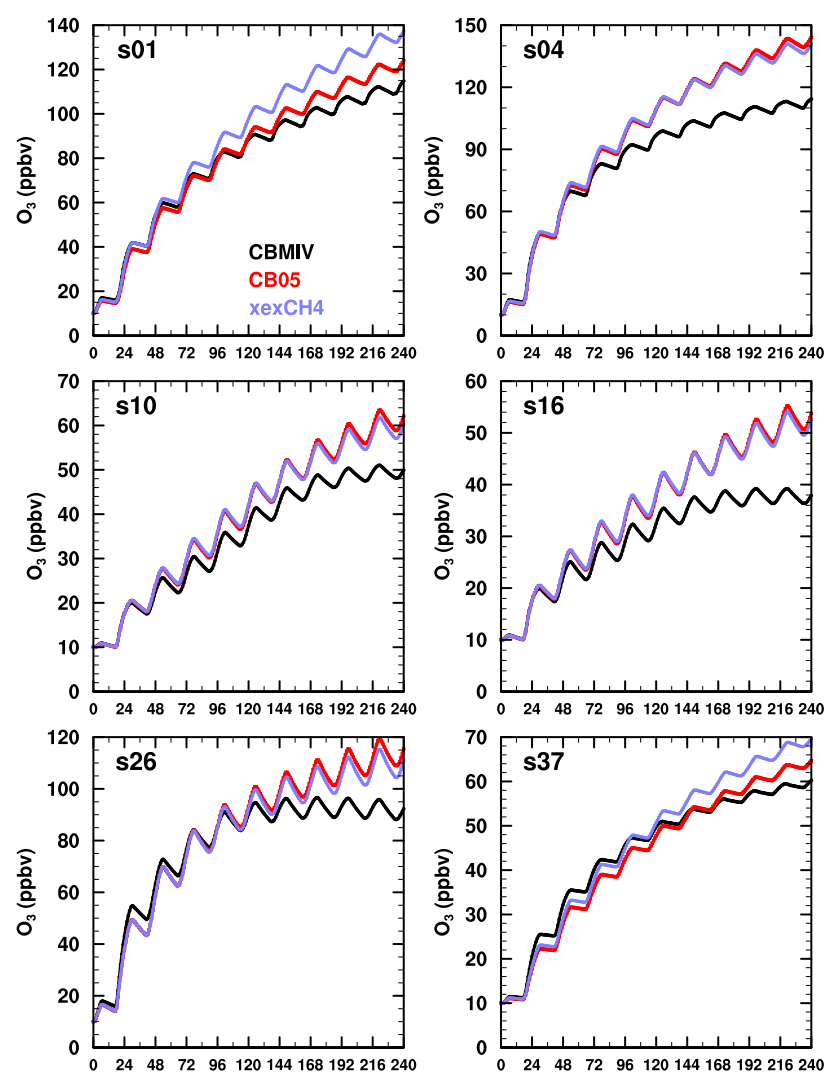

Fig. 4. Example scenario results for sensitivity test xexCH4. Ozone mixing ratios (ppbv) for the base CB05 (red), base CBMIV (black) and sensitivity test xexCH4 (violet) over the $240 \mathrm{~h}$ simulation period.

the reaction of toluene-hydroxyl radical adduct (TO2) with NO was reduced from 1 to 0.1 , while an additional production reaction of NTR involving the new species TERP with $\mathrm{NO}_{3}$ was introduced. Other reactions producing NTR were unchanged and so the overall production of this species is similar between the two mechanisms. However, in CB05 two NTR recycling reactions were introduced

$$
\begin{aligned}
\mathrm{NTR}+\mathrm{OH} \rightarrow & \mathrm{HNO}_{3}+\mathrm{HO} 2+0.33 \mathrm{HCHO} \\
& +0.33 \mathrm{ALD} 2+0.33 \mathrm{ALDX}-0.66 \mathrm{PAR} \\
\mathrm{NTR}+h v \rightarrow & \mathrm{NO}_{2}+\mathrm{HO}_{2}+0.33 \mathrm{HCHO} \\
& +0.33 \mathrm{ALD} 2+0.33 \mathrm{ALDX}-0.66 \mathrm{PAR}
\end{aligned}
$$

In CBMIV, NTR is an irreversible sink of reactive nitrogen species, acting to permanently remove odd-oxygen from the system. In CB05, NTR is no longer a terminal species for reactive nitrogen, but can play a role similar to peroxyacetylnitrate (PAN) to transport and redistribute reactive nitrogen far from its original source location. For sensitivity test xNTRrecycle, the NTR recycling Reactions (R61 and R62) were removed from $\mathrm{CB} 05$, leaving all other reactions as in the base CB05 mechanism. No changes in emissions were made to the scenario suite. 

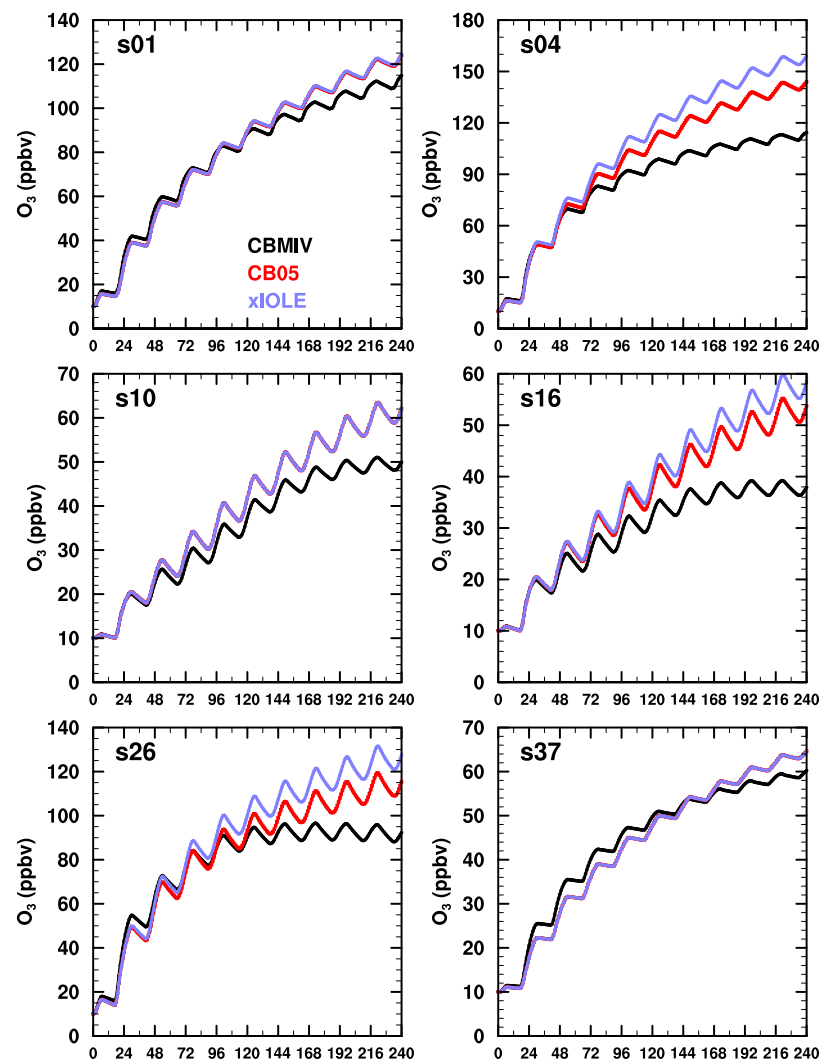

Fig. 5. Example scenario results for sensitivity test xIOLE. Ozone mixing ratios (ppbv) for the base CB05 (red), base CBMIV (black) and sensitivity test xIOLE (violet) over the $240 \mathrm{~h}$ simulation period.

\subsubsection{2 xallNOxrecycle}

Sensitivity test xallNOxrecycle is a combination of tests xiNOxrecycle and xNTRrecycle where all of the newly introduced reactive nitrogen recycling Reactions (R51, R52, R53, R61 and R62) were removed from CB05, leaving all other reactions as in the base CB05 mechanism. No emissions changes were made to the scenario suite.

\section{Results and discussion}

The goal of this investigation was to understand the mechanistic reasons why the $\mathrm{CB} 05$ chemical mechanism tends to produce higher $\mathrm{O}_{3}$ concentrations than the CBMIV mechanism, especially in the context of the NAQFC system. Because of this relatively narrow focus, in this discussion we concentrate only on $\mathrm{O}_{3}$ and its precursors and how the sensitivity tests shed light on the higher $\mathrm{O}_{3}$ concentrations produced by CB05.

Results from the sensitivity tests can be grouped into three categories. First, five of the sensitivity tests (xH2, xoddH\&O, xNO3night, xETHA and xALDX) demonstrated little or no impact on $\mathrm{O}_{3}$ concentrations. In other words, the mechanism
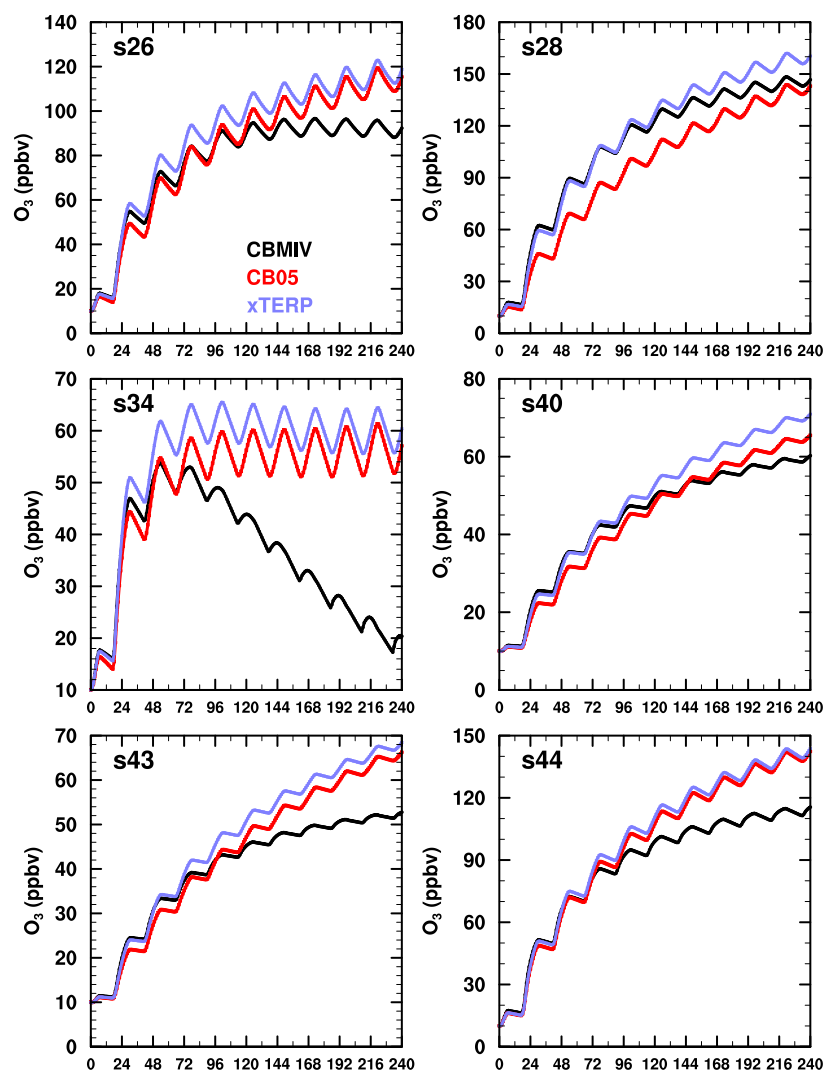

Fig. 6. Example scenario results for sensitivity test xTERP. Ozone mixing ratios (ppbv) for the base CB05 (red), base CBMIV (black) and sensitivity test XTERP (violet) over the $240 \mathrm{~h}$ simulation period.

updates exercised by these five sensitivity tests did not account for the observed larger $\mathrm{O}_{3}$ produced by $\mathrm{CB} 05$. An example of this is presented in Fig. 3, where selected simulation scenario results for sensitivity test XALDX are compared with the base CB05 and CBMIV results for ozone. Ozone concentrations from xALDX were only slightly less for most of the scenarios than for the base CB05 runs. Results for $\mathrm{xH} 2$, xoddH\&O, xNO3night, and xETHA were similarly negative. Consequently, none of the mechanism changes probed by these sensitivity tests account for the higher $\mathrm{O}_{3}$ obtained from CB05.

The second group of sensitivity tests (xexCH4, xIOLE, and xTERP) exhibited a more substantial change in $\mathrm{O}_{3}$ concentrations (Figs. 4-6), but either in the wrong direction to explain the observed differences between CB05 and CBMIV or only exhibited the changes for a limited subset of scenarios. Figure 4 presents results from sensitivity test xexCH4. Removing the explicit $\mathrm{CH}_{4}$ chemistry and returning the mechanism to the CBMIV representation resulted in most simulation scenarios, e.g., s04, s10, s16 and s26, exhibiting little change in $\mathrm{O}_{3}$ concentrations. In a few of the scenarios, e.g., s01 and s37, $\mathrm{O}_{3}$ concentrations actually moved further away from the CBMIV results, in cases with 

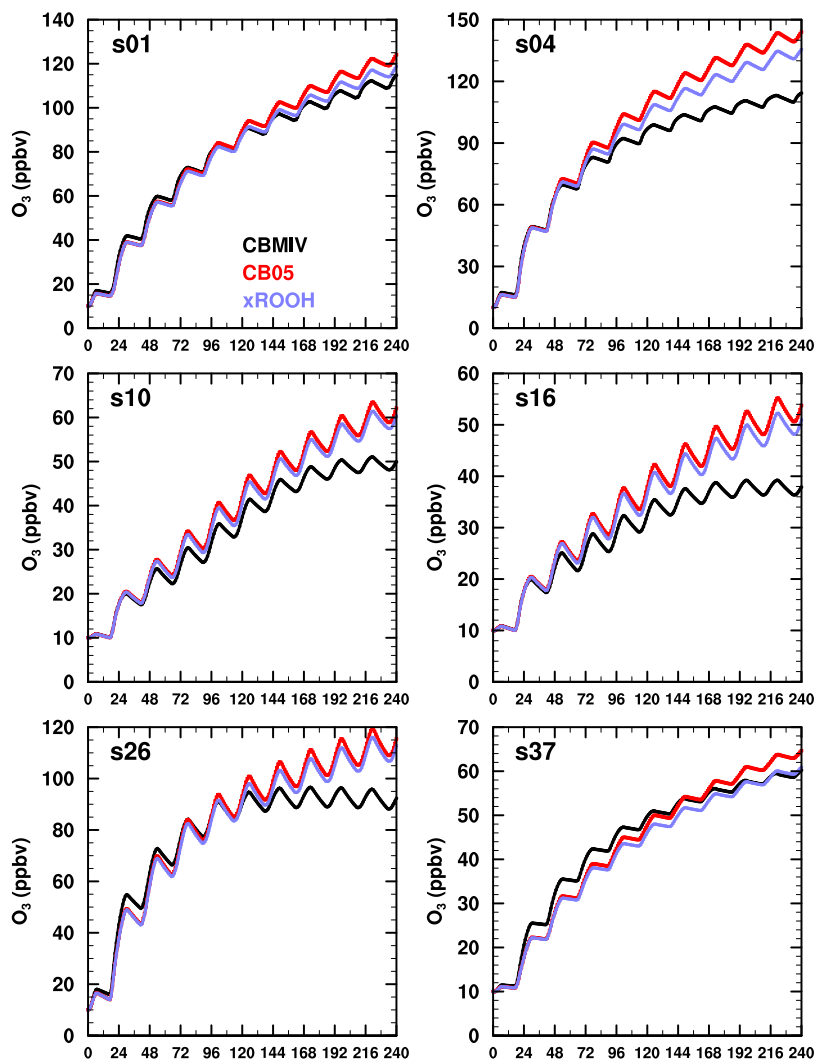

Fig. 7. Example scenario results for sensitivity test xROOH. Ozone mixing ratios (ppbv) for the base CB05 (red), base CBMIV (black) and sensitivity test $\mathrm{xROOH}$ (violet) over the $240 \mathrm{~h}$ simulation period.

low $\mathrm{NO}_{\mathrm{x}}$ emissions where Reaction (R66') produces higher overall concentrations of peroxy radicals than does the explicit representation of MEO2. Figure 5, for sensitivity test xIOLE, presents similar results. Scenarios s01, s10 and s37 showed little change in $\mathrm{O}_{3}$ concentrations, while scenarios s04, s16 and s26 exhibited increases in $\mathrm{O}_{3}$, again moving further away from the CBMIV results. In these cases, the removal of explicit internal olefin chemistry resulted in a decrease in the amount of reactive nitrogen tied up in $\mathrm{HNO}_{3}$ and NTR, allowing greater $\mathrm{O}_{3}$ production. Finally, in Fig. 6 , results from sensitivity test XTERP are presented. These results demonstrate that converting the explicit TERP chemistry introduced in CB05 back into the CBMIV representation (accounting for terpenes as a combination of ALD2, OLE and PAR) actually slightly increases $\mathrm{O}_{3}$ production in most chemical regimes. Thus, the introduction of the explicit TERP chemistry in $\mathrm{CB} 05$ effectively reduced $\mathrm{O}_{3}$ production as compared to CBMIV for a given terpene emissions rate and the higher observed $\mathrm{O}_{3}$ produced by $\mathrm{CB} 05$ cannot be accounted for by the introduction of explicit TERP chemistry.

The third group of sensitivity tests (xROOH, xiNOxrecycle, xNTRrecycle, and xallNOxrecycle) demonstrated the
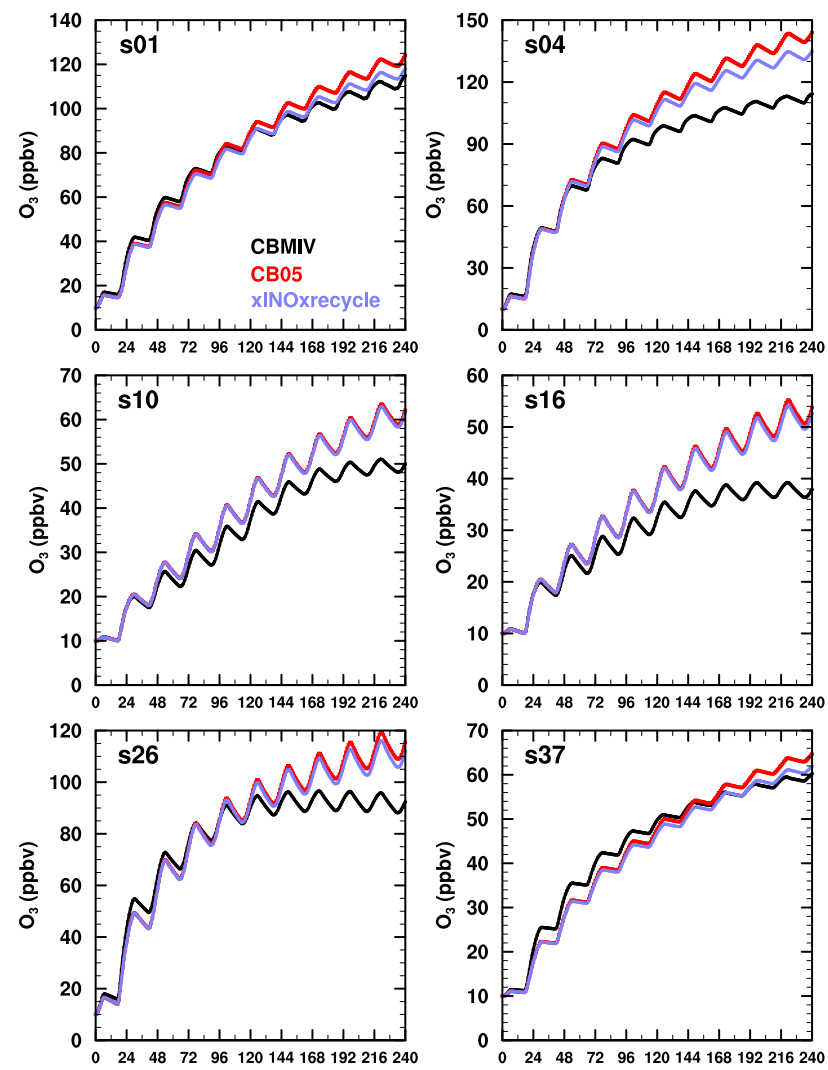

Fig. 8. Example scenario results for sensitivity test xiNOxrecycle. Ozone mixing ratios (ppbv) for the base CB05 (red), base CBMIV (black) and sensitivity test xiNOxrecycle (violet) over the $240 \mathrm{~h}$ simulation period.

most relevant changes in $\mathrm{O}_{3}$ concentrations to the observed differences between CB05 and CBMIV. First, results for sensitivity test $\mathrm{xROOH}$ are presented in Fig. 7. In most simulation scenarios, removing Reactions (R63) and (R64) (thus returning $\mathrm{ROOH}$ to an inert end product species) reduces the amount of $\mathrm{O}_{3}$ produced in the simulations. The introduction of Reactions (R63) and (R64) in CB05 increases the pool of peroxy radicals through direct production of $\mathrm{HO}_{2}$ and $\mathrm{XO} 2$ and indirectly through the production of additional higher aldehydes. However, as seen in Fig. 7, this mechanism change alone only partially accounts for the higher observed CB05 concentrations.

The sensitivity tests xiNOxrecycle and xNTRrecycle (Figs. 8 and 9) are similar to each other in that in each nitrogen is recycled from more stable forms $\left(\mathrm{HO}_{2} \mathrm{NO}_{2}, \mathrm{HNO}_{3}\right.$ and $\mathrm{N}_{2} \mathrm{O}_{5}$ and NTR) back to the more reactive forms $\mathrm{NO}_{2}$ and/or $\mathrm{NO}_{3}$. As can be seen from the selected simulation scenario results for these tests, the introduction of these reactive nitrogen recycling reactions in $\mathrm{CB} 05$ has a significant impact on the production of $\mathrm{O}_{3}$. For xiNOxrecycle (Fig. 8), the urban-like scenarios (e.g., s01 and s04) exhibit the largest impacts since the concentrations of the inorganic nitrogen 

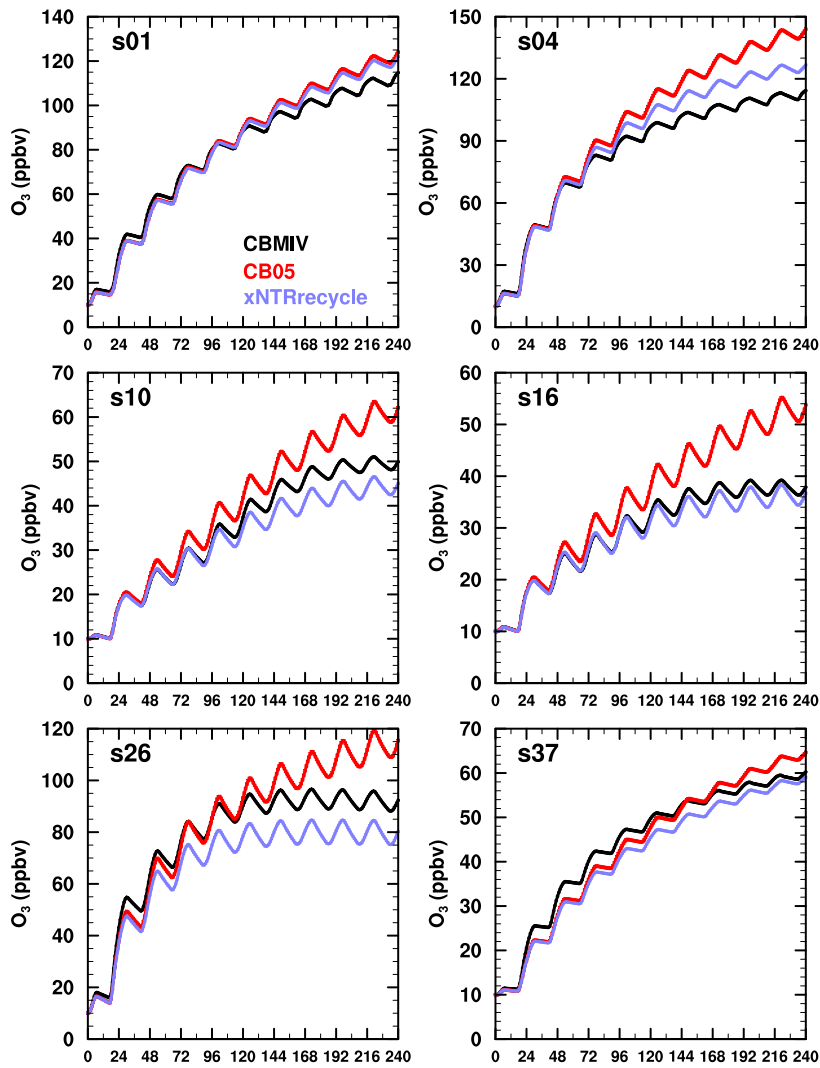

Fig. 9. Example scenario results for sensitivity test xNTRrecycle. Ozone mixing ratios (ppbv) for the base CB05 (red), base CBMIV (black) and sensitivity test xNTRrecycle (violet) over the $240 \mathrm{~h} \mathrm{sim-}$ ulation period.

compounds are larger in these than in the rural-like scenarios (e.g., s10 and s16). On the other hand, for xNTRrecycle (Fig. 9), the lack of $\mathrm{NO}_{2}$ recycling from NTR has a significant impact in most of the scenarios, except those in which little NTR is produced initially (e.g., s01). The combination of the two sets of mechanism changes is tested with xallNOxrecycle, shown in Fig. 10, and demonstrates that these nitrogen recycling pathways as a group have a large impact on $\mathrm{O}_{3}$ production in all chemical regimes. In CBMIV, the lack of these recycling pathways (Reactions R51, R52, R53 and R62) effectively reduces the total amount of reactive nitrogen available in the system through which $\mathrm{O}_{3}$ can be produced by tying up a fraction of emitted $\mathrm{NO}_{\mathrm{x}}$ in $\mathrm{HO}_{2} \mathrm{NO}_{2}, \mathrm{HNO}_{3}, \mathrm{~N}_{2} \mathrm{O}_{5}$ and especially NTR. Inclusion of these pathways in $\mathrm{CB} 05$ enhances the effective pool of reactive nitrogen for a given fixed emissions scenario. These results clearly indicate that introducing these recycling pathways has a large impact on $\mathrm{O}_{3}$ production in the system and can substantially account for the higher production of CB05 as compared to CBMIV.
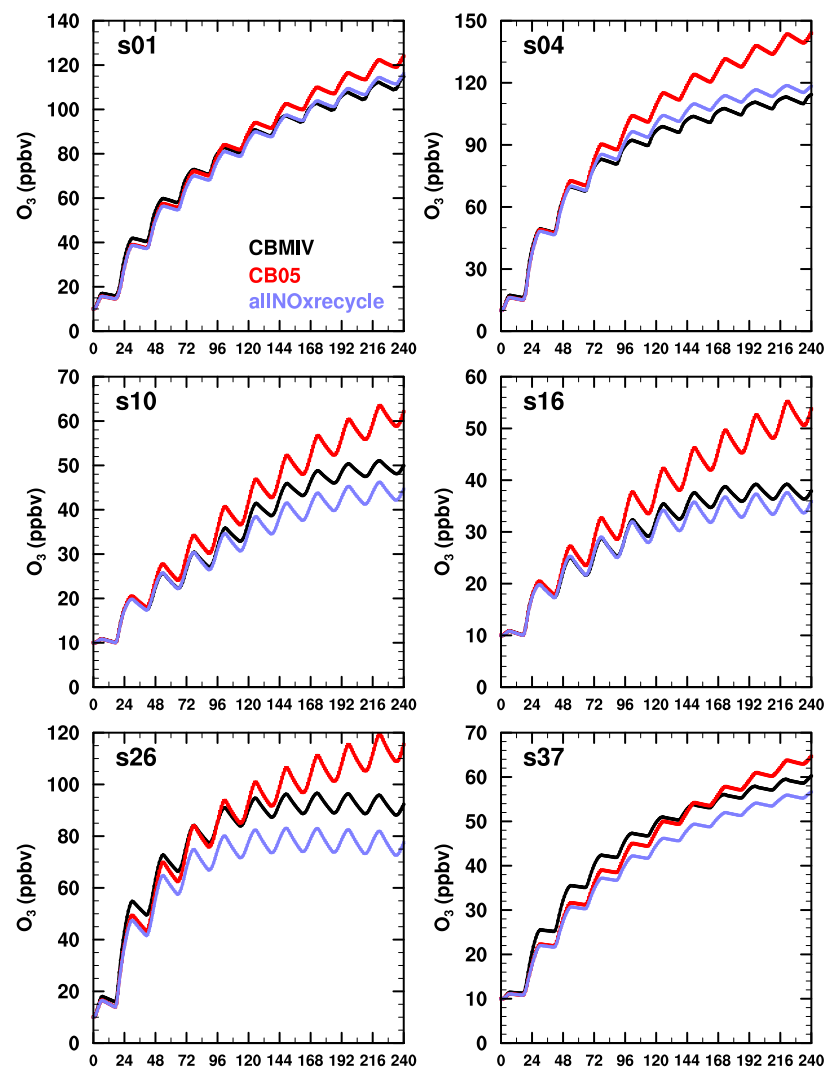

Fig. 10. Example scenario results for sensitivity test allNOxrecycle. Ozone mixing ratios (ppbv) for the base CB05 (red), base CBMIV (black) and sensitivity test allNOxrecycle (violet) over the $240 \mathrm{~h}$ simulation period.

\section{Conclusions and implications}

A box model investigation of mechanistic differences between CB05 and CBMIV was conducted to determine the underlying reasons why $\mathrm{CB} 05$ has been observed to consistently produce higher $\mathrm{O}_{3}$ concentrations than CBMIV for a given set of simulation conditions. By performing sensitivity tests to isolate the conceptual groupings of mechanism differences between CB05 and CBMIV, this study has identified two sets of reactions that are the primary causes of the greater $\mathrm{O}_{3}$ production observed in $\mathrm{CB} 05$. First, the introduction of Reactions (R63) and (R64) in CB05, where the higher organic peroxide species reacts to produce peroxy radicals directly (as $\mathrm{HO}_{2}$ and $\mathrm{XO} 2$ ) and indirectly (via production of higher aldehydes) results in higher $\mathrm{O}_{3}$ concentrations in most chemical regimes. Second, the introduction in CB05 of recycling pathways for reactive nitrogen (via Reactions R51, R52, R53 and R62) effectively increases the amount of $\mathrm{NO}_{x}$ available in the system for a given emissions rate.

In the context of a large-scale three-dimensional air quality simulation such as the NAQFC, the reactive nitrogen recycling reactions are particularly effective in producing larger 
$\mathrm{O}_{3}$ concentrations throughout the model domain. In particular, the organic nitrate species, NTR, plays a role much as the PAN species, serving as a temporary reservoir of reactive nitrogen. NTR can be formed efficiently through a variety of pathways in the CB05 mechanism (Reactions R55, R115, $\mathrm{R} 129, \mathrm{R} 133, \mathrm{R} 144, \mathrm{R} 147, \mathrm{R} 152, \mathrm{R} 156)$ and is formed at the highest rates near significant $\mathrm{NO}_{\mathrm{x}}$ sources. Since the lifetime of NTR with respect to its most significant chemical loss process (Reaction R62) is about 4 days, it can be transported relatively long distances away from major sources before $\mathrm{NO}_{2}$ is regenerated. If this recycling process occurs in $\mathrm{NO}_{\mathrm{x}}$-sensitive areas, significant additional $\mathrm{O}_{3}$ can be produced. Through this process, $\mathrm{NO}_{\mathrm{x}}$, which is emitted from large sources in $\mathrm{NO}_{\mathrm{x}}$-saturated chemical regimes where it may not produce much additional $\mathrm{O}_{3}$, can be redistributed to more remote locations which may be $\mathrm{NO}_{\mathrm{x}}$-sensitive, thereby increasing the $\mathrm{O}_{3}$-production efficiency of each emitted $\mathrm{NO}_{\mathrm{x}}$ molecule.

As previous studies have indicated (Yarwood et al., 2005; Sarwar et al., 2008; Luecken et al., 2008), the CB05 mechanism is a better representation of the state-of-the-science (as of 2005) of gas phase chemistry than is the CBMIV mechanism. The fact that the NAQFC operational version, which uses the CBMIV mechanism, produces ground-level $\mathrm{O}_{3}$ concentrations which have smaller biases with respect to measurements (Fig. 1) than does the CB05 version implies that the operational NAQFC system contains other compensating errors that allow it to produce better results for $\mathrm{O}_{3}$. In order to move the NAQFC system forward to further improve its forecasting capabilities, these compensating errors need to be uncovered and corrected.

\section{Supplementary material related to this article is available online at: http://www.geosci-model-dev.net/5/257/2012/ gmd-5-257-2012-supplement.pdf.}

Acknowledgements. The authors thank current and former members of the NOAA Air Resources Laboratory air quality modeling group (Pius Lee, Tianfeng Chai, Yunsoo Choi, Yunhee Kim, HyunCheol Kim, Hsin-Mu Lin, Fantine Ngan and Daniel Tong) for many useful discussions during the conduct of this work. RS also thanks Golam Sarwar of the US Environmental Protection Agency for helpful discussions and insight into the issues investigated here. The authors dedicate this manuscript to the memory of Daewon Byun (1956-2011), who inspired the initiation of this investigation.

Edited by: A. Kerkweg

\section{References}

Byun, D. and Schere, K. L.: Review of the governing equations, computational algorithms, and other components of the Models3 Community Multiscale Air Quality modeling system, Appl. Mech. Rev., 59, 51-77, 2006.

Eder, B., Kang, D., Mathur, R., Pleim, J., Yu, S., Otte, T., and Pouliot, G.: A performance evaluation of the National Air Quality Forecast Capability for the summer of 2007, Atmos. Environ., 43, 2312-2320, 2009.

Gery, M. W., Whitten, G. Z., Killus, J. P., and Dodge, M. C.: A photochemical mechanism for urban and regional scale computer modeling, J. Geophys. Res., 94, 12925-12956, 1989.

Janjic, Z. I.: A nonhydrostatic model based on a new approach, Meteorol. Atmos. Phys., 82, 271-285, 2003.

Luecken, D. J., Tonnesen, G. S., and Sickles II, J. E.: Differences in $\mathrm{NO}_{y}$ speciation predicted by three photochemical mechanisms, Atmos. Environ., 33, 1073-1084, 1999.

Luecken, D. J., Phillips, S., Sarwar, G., and Jang, C.: Effects of using the CB05 vs. SAPRC99 vs. CB4 chemical mechanism on model predictions: ozone and gas-phase photochemical precursor concentrations, Atmos. Environ., 42, 5805-5820, 2008.

Otte, T., Pouliot, G., Pleim, J., Young, J., Schere, K., Wong, D., Lee, P., Tsidulko, M., McQueen, J., Davidson, P., Mathur, R., Chuang, H.-Y., DiMego, G., and Seaman, N.: Linking the Eta model with the Community Multiscale Air Quality (CMAQ) modeling system to build a national air quality forecasting system, Weather Forecast., 20, 367-384, 2005.

Sandu, A. and Sander, R.: Technical note: Simulating chemical systems in Fortran90 and Matlab with the Kinetic PreProcessor KPP-2.1, Atmos. Chem. Phys., 6, 187-195, doi:10.5194/acp-6187-2006, 2006.

Sarwar, G., Luecken, D., Yarwood, G., Whitten, G., and Carter, W. P. L.: Impact of an updated carbon bond mechanism on predictions from the CMAQ modeling system: preliminary assessment, J. Appl. Meteorol. Climatol., 47, 3-14, 2008.

Seinfeld, J. H. and Pandis, S. N.: Atmospheric Chemistry and Physics: From Air Pollution to Climate Change, John Wiley \& Sons, Inc., New York, 1998.

Yarwood, G., Rao, S., Yocke, M., and Whitten, G. Z.: Updates to the Carbon Bond Chemical Mechanism: CB05, RT-04-00675, Final Report to US Environmental Protection Agency, Yocke and Company, Novato, CA, December 2005.

Yu, S., Mathur, R., Sarwar, G., Kang, D., Tong, D., Pouliot, G., and Pleim, J.: Eta-CMAQ air quality forecasts for $\mathrm{O}_{3}$ and related species using three different photochemical mechanisms (CB4, CB05, SAPRC-99): comparisons with measurements during the 2004 ICARTT study, Atmos. Chem. Phys., 10, 30013025, doi:10.5194/acp-10-3001-2010, 2010.

Zaveri, R. and Peters, L. K.: A new lumped structure photochemical mechanism for large-scale applications, J. Geophys. Res., 104, 30387-30415, 1999. 